\title{
Novel Function of Lycopene in Vascular Endothelial Cell
}

\author{
Jingu Cho, Sunghyen Kim, Jeonghwa Seo, Sunyoung Ahn, Eunsil Jeong and Heonyong Park*
}

Department of Molecular Biology \& Insitute of Nanosensor and Biotechnology, BK21 Graduate Program for RNA Biology, Dankook University, Yongin-si, Gyeonggi-do, 448-701, Korea

Received April 12, 2010 / Accepted April 29, 2010

\begin{abstract}
Little is known about the cardiovascular effects of Lycopene, an anti-cancer and anti-oxidative agent. In this study, we executed a series of experiments with vascular endothelial cells to disclose the cardiovascular functions of lycopene. From our in vitro experiments, lycopene was determined to act as a stimulant to induce endothelial cell proliferation and migration. In addition, lycopene was shown to inhibit lipopolysaccharide (LPS)-induced adhesion of THP-1 leukocytes to endothelial cells, as well as activating mitogen activated protein kinase (MAPK) family members, ERK, JNK and p38 MAPK. Both ERK and p38 MAPK were involved in lycopene-induced cell proliferation, while JNK was involved in lycopene-dependent cell migration. Taken together, lycopene activates MAPK family members which regulate cell proliferation and migration. Lycopene differentially blocks LPS-dependent adhesion for THP-1 to endothelial cells, indicating that lycopene is likely to regulate a variety of vascular functions.
\end{abstract}

Key words : Lycopene, endothelial cells, proliferation, migration, adhesion

\section{서 론}

Lycopene은 phytochemical의 하나이며, $\beta$-carotene이나 lutein과 같은 카르티노이드계 색소 물질이다[24]. Lycopene 은 카르티노이드계 색소를 함유 하는 붉은색 계열의 과일 및 채소에 풍부하게 존재한다. Lycopene은 인간의 생존에 요구 되는 필수 영양소는 아니며, 대부분의 경우 체내에서 생합성 대사에 의하여 생성되기보다는 음식을 통한 섭취를 통하여 체내에 축적된다. Lycopene의 체내 이동은 다양한 지방 단백 질(lipoprotein)을 통해 혈액을 따라 수송되어 간(liver), 부신 (adrenal glands) 그리고 고환(testes) 등에 축적이 된다[22].

Lycopene의 잘 알려진 기능성은 항산화 기능(antioxidant activity)이다. Lycopene은 vitamin E 보다 효율적으로 reactive oxygen species (ROS)을 제거하는 것은 물론, $\beta$ -carotene 이상의 강력한 항산화 작용을 보유하고 있어서 노화 방지, 항암 효과 작용 등의 효능이 알려져 있다[20].

현재까지 알려진 lycopene의 항암 기능에 관한 세포수준의 효과는 PDGF-BB (platelet-derived growth factor-BB)로 부터 유도되는 세포신호전달(cell signal transduction)과 세포이동 (cell migration)이 lycopene에 의해 억제되며, 이와 같은 세포 신호전달 및 세포이동의 억제는 세포사멸(apoptosis) 유발과 세포증식(proliferation)억제 등 항암 효과와 상관관계가 매우 높다[27]. 항암 효과에 관한 lycopene의 연구는 오랫동안 진행 되어 왔다. 그러나 lycopene의 혈관 기능 효과에 관한 연구는

*Corresponding author Tel : +82-31-8005-3193, Fax : +82-31-8005-3191

E-mail : heonyong@dankook.ac.kr
미미한 상태이기 때문에 심층적 연구가 보다 많이 진행되어야 한다.

현재까지의 연구결과들을 토대로 보면 lycopene은 항산화 기능과 연계된 혈관 생리 기능을 보유할 가능성이 매우 높다. 그 이유는 lycopene은 내피세포에서 $\mathrm{H}_{2} \mathrm{O}_{2}$ 에 의해 생성되는 산화적 손상을 감소시키고, LDL (low density lipoprotein)의 산화를 억제하기 때문이다. LDL의 산화억제기능은 동맥경화 발생을 억제하는데 매우 중요하다. 또한 lycopene은 TNF-a에 의해 유도되는 ICAM-1의 발현 억제시켜 adhesion molecule 의 생산을 감소시키기 때문에 항염증 반응에도 효능이 있을 것으로 예측된다[7,26].

혈관 질환 중 대표적인 동맥경화의 초기 증상은 염증반응으 로부터 유도된다. 이러한 초기 증상은 최초 LDL이 결체조직 으로 들어와 산화 작용을 거치게 되면서 내피세포에서의 케모 카인(chemokine) 분비를 유도하게 된다. 이러한 케모카인은 단핵구(monocyte) 및 혈구 세포를 불러와 내피세포와의 부착 을 통하여 결체조직 안으로 이동(trans-endothelial migration) 이 되어, 대식세포(macrophage) 및 포말세포(foam cell)로 분 화(differentiation)된 후, 콜레스테롤 등의 축적이 이루어진다 [3]. 따라서 동맥경화 발생은 단계별로 진행되는 여러 가지 세 포 현상이 관여하고 있기 때문에, lycopene이 동맥경화 발생 진행 단계에 어떤 영향을 미치는 지 알기 위해서는 적절한 세포모델 시스템을 적용하는 연구가 수행되어야 한다.

본 연구에서는 토마토에서 분리 정제한 lycopene이 혈관에 서 작용하는 생리적 기능을 이해하기 위해, 혈관 내피 세포의 성장, 세포사멸, 혈관 내 상처 치유 및 새로운 혈관 형성 과정 중의 하나인 혈관 내피 세포의 이동, 동맥경화 발생 초기 증상 
인 이종 세포간 부착현상(heterotypic THP-1 cell adhesion)과 lycopene에 의한 세포 내 신호전달의 변화를 관찰하여, lycopene이 혈관에 기여하는 역할을 이해하고자 하였다.

\section{재료 및 방법}

\section{재료}

Lycopene은 Sigma-Aldrich (USA)사에서 제공하는 시약을 구입하여 DMSO에 녹여 사용하였다.

\section{세포배양}

소 대동맥 내피세포(Bovine Aortic Endothelial Cell: $\mathrm{BAEC})$ 은 세포 외 기질에 부착하여 자라는 부착세포(adhesion cell)로, 소의 대동맥에서 추출한 후 계대 수 3 에서 8 사이의 일차세포를 실험에 사용하였다. BAEC은 $20 \%$ 소태아혈청 (fetal bovine serum: FBS, Wel GENE Inc., Korea)과 0.5\% L-Glutamine, $0.5 \%$ 항생제(streptomycin/penicillin)가 포함된 DMEM (glucose $1 \mathrm{~g} /$ liter Wel GENE Inc.)을 이용하여 $37^{\circ} \mathrm{C}$, $5 \% \mathrm{CO}_{2}$ 조건에서 배양하였다.

THP-1 (human acute monocytic leukemia cells)은 부유세 포(suspension cell)로 T-25 flask에 배양하였으며, $10 \%$ 소태아 혈청과 $\quad 0.5 \%$ 항생제(streptomycin/penicillin)가 포함된 $\mathrm{RPMI} 1640$ (Wel Gene Inc.)를 이용하여 $37^{\circ} \mathrm{C}, 5 \% \mathrm{CO}_{2}$ 조건에 서 배양하였다.

\section{세포성장 실험}

세포성장은 WST (high sensitive water soluble tetrazolium salt)를 이용하여 살아있는 세포내의 dehydrogenase와 반응 정도를 측정하여 평가하였다. 혈청기아 상태인 $\mathrm{DMEM}$ 에 $\mathrm{BAEC}$ 을 16시간 동안 배양한 후, 다양한 농도의 lycopene을 처리한 뒤, 시간 별로 microplate leader (BIO-RAD, USA)를 이용하여 $450 \mathrm{~nm}$ 에서 흡광도를 측정하였다.

\section{세포사멸 실험}

전면 성장한 $\mathrm{BAEC}$ 을 $0.5 \% \mathrm{FBS}$ 가 첨가된 $\mathrm{DMEM}$ 에 16 시간 동안 배양한 후 다양한 농도의 lycopene을 처리하였고, 양성 대조군으로 etoposide (Sigma-Aldrich) $100 \mu \mathrm{M}$ 을 처리하였다. 총 처리 시간은 24 시간 이었고, 시간 경과에 따른 변화를 현미 경으로 관찰하여 기록하였으며, 세포사멸 세포(탈착, 원형인 부유 상태에 있는 세포)를 계산하여 세포사멸 비율을 결정하 였다.

\section{세포이동 실험}

전면 성장한 BAEC에 $2 \mathrm{mM}$ thymidin (Sigma-Aldrich)를 24 시간 동안 처리하여 세포의 성장을 중지시킨 후 $\mathrm{PBS}$ (phosphate buffered saline)로 2회 세척하였다. 그 후 스크래 퍼(scraper)를 이용하여 창상선을 만든 후 다시 PBS로 2회 세 척한 뒤 각 농도 별로 lycopene을 처리하여 24시간까지 시간 별로 확인하였다. 세포이동 정도는 동일 배율로 관측되는 현 미경 시야 내의 일정한 크기의 구역(visual field)으로 이동한 세포 수를 세어 평가하였다.

\section{세포부착 실험}

$\mathrm{BAEC}$ 을 전면 성장 시킨 후에 혈청 기아배지를 이용하여 16 시간 동안 추가로 배양했다. 또한 THP-1세포를 배양한 후 $10 \mu \mathrm{M}$ 의 Calcein $\mathrm{AM}$ (Sigma-Aldrich)을 $37^{\circ} \mathrm{C}, 5 \% \mathrm{CO}_{2}$ 조건 에서 45 분간 염색시키고, $\mathrm{PBS}$ 를 이용하여 3회 세척하였다. Calcein AM으로 염색시킨 THP-1을 BAEC이 부착된 기판 위 에 동량으로 첨가하여, 부착된 THP-1 세포를 형광 현미경으로 관찰하였다. 부착된 세포와 전체 세포의 비율을 계산하여 정 량화 하였다.

\section{Western Blot}

전면 성장한 $\mathrm{BAEC}$ 에 $10 \mu \mathrm{M}$ 의 lycopene을 $0,5,15,30,60$ 분 동안 처리한 후 분해 완충액 $(50 \mathrm{mM}$ Tris, $150 \mathrm{mM} \mathrm{NaCl}$, $0.1 \mathrm{mM}$ PMSF, $1.0 \mathrm{mM}$ Na Vanadate, 1\% [v/v] Triton X-100, $10.0 \%$ Glycerol, pH 7.4)으로 분해 시킨 뒤 원심분리한 상층액 을 획득하여 $\mathrm{BCA}$ assay로 단백질 정량을 하고 동일한 양의 단 백질을 SDS-PAGE (sodium dodecyl sulfate polyacrylamide gel electrophoresis)에 의해 분리 시켰다. 분리 시킨 단백질은 PVDF (polyvinylidene fluoride) 막으로 이동시켜 고정하고 분석하고자 하는 표적 단백질에 해당하는 1 차 항체는 p eNOS, p ERK, p p38, p JNK (Cell signaling, Danvers, MA, USA) 와 Actin (Santa Cruz, CA, USA)을 표적으로 하는 항체로 원액을 $1: 1,000$ 비율로 희석하여 반응시켰다. 2차 항체 는 HRP conjugated goat anti rabbit 또는 mouse 항체 (Millipore, Billerica, MA, USA)를 1:2,000 비율로 희석한 후 사용하였다. 2차 항체 반응 후 화학발광 검출법을 통해 X-ray film에 발광 부위를 노출한 후 단백질 검출을 하였고, 이를 통해 세포 신호 전달 분자의 활성 변화를 관찰하였다.

\section{단백질 인산화 효소 및 산화질소 생산 효소 억제}

단백질 인산화 효소 및 산화질소 생산효소 억제제를 처리하 여 세포성장, 이종세포 간의 부착 및 세포이동에 어떠한 영향 을 미치는 지 알아보기 위하여, 혈청기아 상태인 $\mathrm{DMEM}$ 에 $\mathrm{BAEC}$ 을 16시간 동안 배양한 후, SB-203580 $(10 \mu \mathrm{M}, \mathrm{p} 38$ MAPK 억제자, Enzo Life Sciences, USA), SP-600125 (10 $\mu \mathrm{M}$,

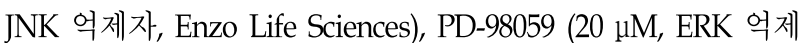
자, Enzo Life Sciences) 그리고 L-NAME $(2.5 \mu \mathrm{M}$, eNOS 억제 자, Sigma-Aldrich)의 인산화 억제제를 1 시간 동안 처리 한 후 lycopene $10 \mu \mathrm{M}$ 을 처리하여 세포성장 및 세포이동 실험을 전에 기술한 방법과 동일하게 수행하였다. 


\section{통계분석}

실험결과는 mean \pm S.E로 나타내었고 분석된 데이터는 실험 자료로부터 one-way ANOVA를 이용하여 유의성이 있을 경 우 post-hoc test를 실시하여 $95 \%$ 수준에서 유의성을 검증하였다.

\section{실험결과}

\section{혈관내피세포 성장 실험결과}

본 연구자들은 lycopene이 혈관내피세포의 세포생물학적 기능에 미칠 수 있는 효과를 알기 위한 일련의 실험들을 수행 하였다. 먼저, 혈관 내피세포 성장에 lycopene이 어떤 역할을 하는지 알기 위하여, 소 대동맥 내피세포에 lycopene을 전 처 리한 후 세포성장이 대조군과 어떤 차이가 있는지 조사해 보 았다. Lycopene의 전 처리는 다양한 농도 $(0 \sim 10 \mu \mathrm{M})$ 로 처리하 였으며, WST assay로 세포성장 정도를 평가하였다. Lycopene 의 처리시간 및 농도 별 세포성장 실험결과는 Fig. 1에서 보는 것과 같이, lycopene의 농도가 증가할수록 세포성장이 증가함 을 볼 수 있었다. 이와 같이 농도 의존적으로 세포성장이 증가 하는 것은 lycopene이 혈관내피세포의 성장을 촉진시킴을 의 미한다.

\section{혈관내피세포 사멸 실험결과}

위의 결과에서 보듯이 lycopene이 혈관내피세포의 성장을 촉발하였으므로, 본 연구자들은 세포성장과 반대 기능인 내피 세포의 세포사멸에는 lycopene이 어떠한 영향을 끼치는지 조 사하였다. 내피세포는 세포 외 기질에 부착하여 성장하는 세 포로서 세포사멸이 일어나면, 세포는 원형의 탈착부유 세포로 변한다. 따라서 원형의 탈착부유 세포 수를 세어 전체 세포 수에 대한 원형부유세포 수의 비율로 세포사멸 정도를 결정하 였다. 세포사멸에 관한 양성 대조군을 얻기 위하여 etoposide 로 세포사멸을 유도하였고, 양성 대조군의 처리조건과 동일하

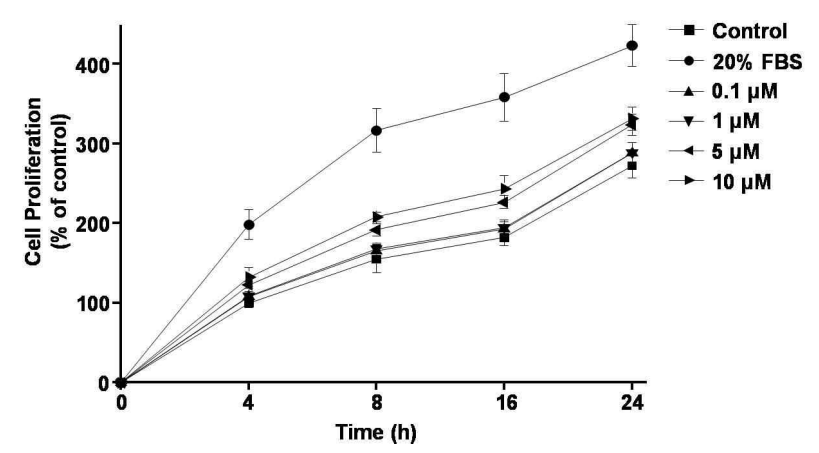

Fig. 1. Lycopene induces endothelial cell proliferation. BAECs were starved for $16 \mathrm{hr}$ and treated with none, 20\% FBS and various concentration of lycopene. Then the cells were incubated with WST-1 reagent for various time. Line graphs represent the percentages of cell proliferation (mean \pm S.E, $n=3$ ).
게 혈청기아 상태에서 lycopene 처리를 함으로써, 세포사멸의 영향에 미치는 lycopene의 영향을 평가하였다. 세포사멸에 관 한 실험결과는 Fig. 2에서 보듯이, 다양한 농도의 lycopene을 처리한 어느 경우에서도 세포사멸의 정도가 음성 대조군의 결과와 의미 있게 차이 나는 실험군이 관찰되지 않았다. 이와 같은 결과는 lycopene이 내피세포의 사멸에는 영향을 미치지 않음을 의미한다.

\section{혈관내피세포의 세포이동 실험}

혈관내피세포의 생리활성 중 하나인 세포이동은 혈관신생 및 상처치유 과정에 일어나는 현상이기 때문에 혈관내피세포 의 세포이동에 관한 lycopene의 효과를 알기 위한 연구는 lycopene의 혈관 기능을 이해하는 데 중요하다. 본 연구에서는 혈 관내피세포에 thymidine을 처리하여 세포성장을 중지시킨 뒤 스크래퍼를 이용하여 창상선을 만든 후 시면적에 이동한 세포 수를 세어 혈관내피세포 이동 정도를 평가하였다. Fig. 3 에서 보듯이 혈관내피세포의 이동 정도는 lycopene의 농도 가 증가함에 따라 증가하는 것을 확인할 수 있었다. 이와 같은 결과를 통하여 lycopene의 혈관기능은 혈관신생 유도 및 상처 치유와도 연계되어 있음을 예측할 수 있다.

\section{백혈구의 내피층 부착에 관한 실험결과}

동맥경화발생은 초기에 혈관 내벽의 염증으로 인해 시작되 는 것으로, 혈관의 염증반응은동맥경화발생과 밀접한 관계가 있다. 염증반응의 초기 단계에는 혈액에 존재하는 백혈구가
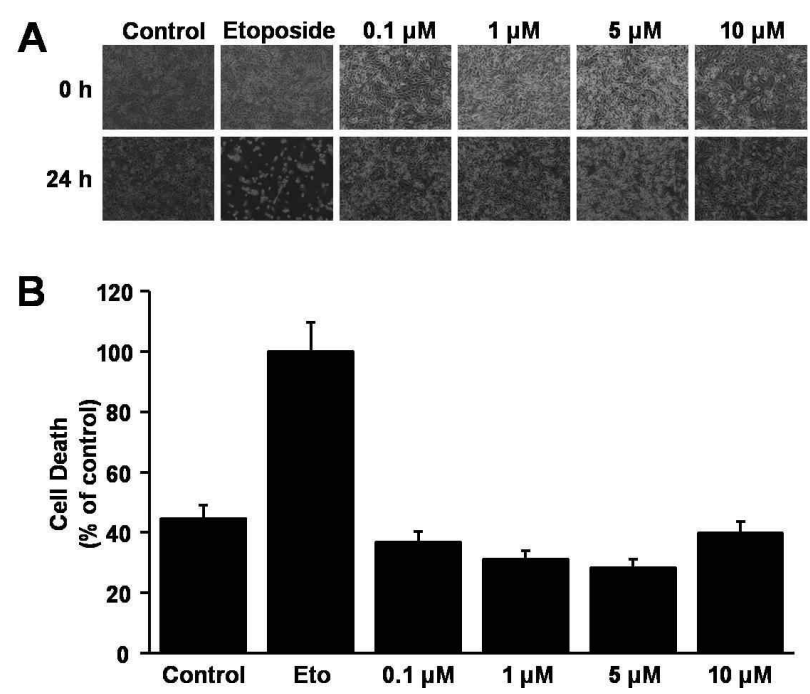

Fig. 2. Lycopene has no effect on endothelial cell death. Confluent BAECs were serum-staved for $16 \mathrm{hr}$ and then the cells were incubated for $24 \mathrm{hr}$ with none, $100 \mu \mathrm{M}$ etoposide (eto), and various concentration of lycopene. Representative pictures were shown in panel A. Then detached round cells were counted under a microscope. In panel $B$, bar graphs show mean \pm S.E $(n=3)$. 

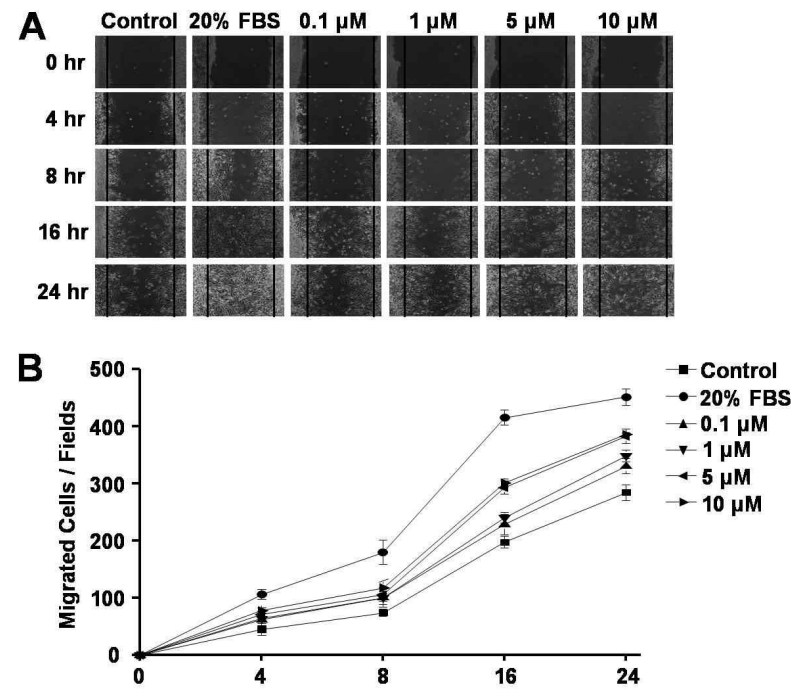

Fig. 3. Lycopene induces endothelial cell migration. Confluent BAECs were incubated with none, 20\% FBS and various concentration of lycopene after treated with $2 \mathrm{mM}$ thymidin for $24 \mathrm{hr}$. Then the cells were scraped by scraper and additionally were incubated for $24 \mathrm{hr}$. Then the migrated cells were observed under a microscope. Representative pictures were shown in panel A. Then the migrated cells were counted in the same visual field. In panel $B$, bar graphs show mean \pm S.E $(n=3)$.

혈관 내피층에 부착된다[13,21]. 즉 백혈구의 혈관 내피층 부착 은 동맥경화 발생의 초기단계의 한 현상이다. 본 연구자들은 백혈구의 in vitro 내피세포 부착실험으로 동맥경화발생에 미 치는 lycopene의 효과를 평가하였다. 양성대조군 실험을 위하 여 lipopolysaccharide (LPS, $1 \mu \mathrm{g} / \mathrm{ml}$, Sigma-Aldrich)를 사용 하였다. LPS는 그람양성균의 세포벽 외막을 구성하는 물질로 염증 반응을 유도한다[9]. 또한 내피세포에 LPS를 처리하게 되면 케모카인의 분비가 유도되어, 분비된 케모카인의 활성으 로 백혈구의 내피층 부착이 일어나게 된다[14]. 실험결과, lycopene을 내피세포에 처리한 경우, LPS에 의해 유도되는 림프 구인 THP-1 세포의 내피세포 부착 정도가 lycopene의 처리 농도가 증가할수록 감소하는 것을 관찰할 수 있었다(Fig. 4). 이와 같은 결과는 lycopene이 혈관내의 염증 반응을 억제할 수 있음을 의미한다.

\section{세포신호전달물질의 활성에 미치는 lycopene의 효과 실험 결과}

Mitogen activated protein kinases (MAPK)는 다양한 세포 생리활성에 관여하는 세포신호전달물질이다[14, 18]. MAPK 중에서 중요한 family member로는 extracellular signal regulated kinase (ERK), c-Jun-N-terminal kinase (JNK), p38 MAPK 등이 있으며 이들은 혈관내피세포의 기능에 다양한 역할을 하고 있다. 한편, 활성화된 $\mathrm{eNOS}$ 에 의해 만들어지는
A
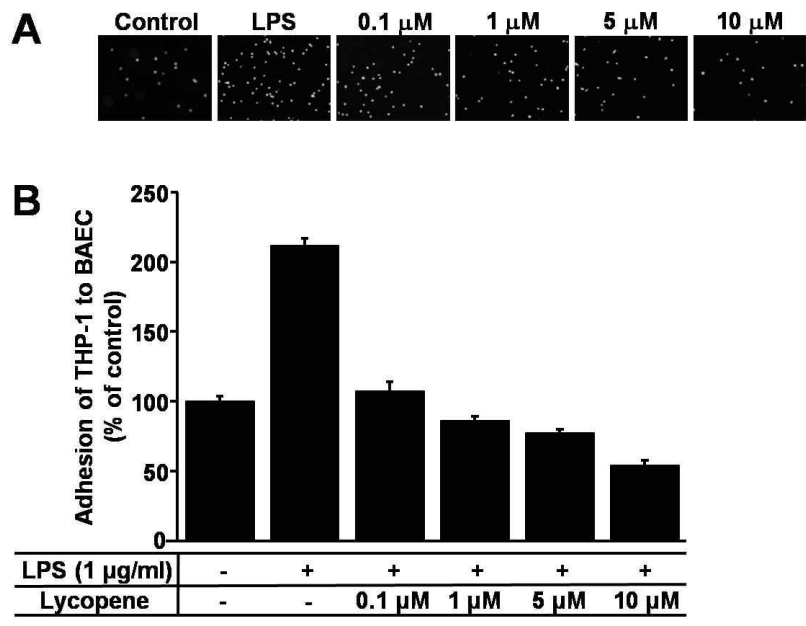

Fig. 4. Lycopene inhibits LPS-induced adhesion of monocyte to endothelial cell. BAECs were serum-starved for $16 \mathrm{hr}$ and then cells were treated for $24 \mathrm{hr}$ with none, $1 \mathrm{\mu g} / \mathrm{ml}$ LPS or various concentration of lycopene. Before adding THP-1 to BAECs, THP- 1 cells $\left(5-6 \times 10^{6}\right.$ cells $\left./ \mathrm{ml}\right)$ were stained with $10 \mu \mathrm{M}$ Calcein AM. Then THP- 1 cells were aliquot into the BAEC culture dishes. After 1 hour additional incubation, adherent cells were observed under a fluorescent microscope. Representative pictures were shown in panel A. Then the adhesive cells were counted in the same visual field. In panel B, bar graphs show mean \pm S.E $(n=3)$.

산화질소(nitric oxide)는 혈관확장, 세포성장에 관여하는 등 혈관내피세포에서 여러가지 중요한 생리적 기능에 관여하는 혈 관 조절인자로 잘 알려져 있다[17]. 따라서 lycopene이 관여 하는 세포생리활성에 이와 같은 세포신호전달물질이 어떤 역 할을 하는지 알기 위한 실험을 진행하였다. 먼저, lycopene이 $\mathrm{MAPK}$ 나 eNOS의 활성을 촉진하는지 알아보았다. 실험 결과, Fig. 5에서 보는 것과 같이 lycopene의 처리는 ERK, p38 $\mathrm{MAPK}$ 그리고 JNK의 활성을 촉진시켰으나, $\mathrm{eNOS}$ 의 경우에 는 영향을 미치지 않았다. MAPK들의 활성 패턴은 ERK, p38 $\mathrm{MAPK}$ 의 경우, 5 분에 인산화가 극대화 되었고, 그 이후 1 시간 까지 활성이 계속 유지된 반면, JNK의 경우는 5 15 분에 활성이 최대치로 되었다가 30 분 이상이 되면 다시 음성 대조 군 수준으로 저하되는 것을 확인하였다.

\section{혈관내피세포 기능에 관여하는 세포신호전달물질 역할 규명} 에 관한 연구 결과

Lycopene에 의해 조절되는 신호전달물질들을 다시 한번 요 약해보면 lycopene은 ERK, p38 MAPK 그리고 JNK의 활성을 촉발하였지만, $\mathrm{eNOS}$ 의 활성에는 아무런 영향을 주지 않았다. 또한 MAPK가 lycopene의 생리활성에 얼마나 특이적으로 관 여하는지 알기 위하여 각 신호전달물질의 억제제를 전 처리한 후 lycopene의 생리활성의 변화를 관찰하였다. 흥미롭게도 


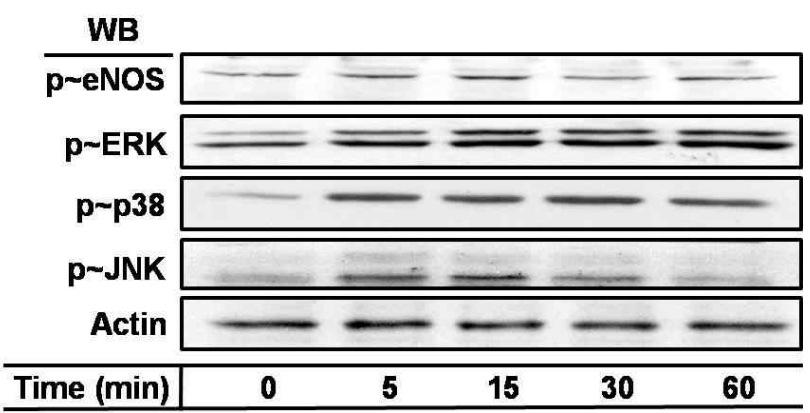

Fig. 5. Lycopene activates MAPKs but not eNOS. BAECs were serum-starved for $16 \mathrm{hr}$ and treated with none, various concentration of lycopene for indicated periods. Proteins of the lysed cells were resolved by SDS-PAGE, electrotransferred to PVDF membranes and immunoblotted with antibodies specific for phopho-ERK, phospho-JNK, phospho-p38 and phospho-eNOS.

p38 MPAK의 억제제인 SB-203580와 ERK의 억제제인 PD-98059 의 전 처리는 lycopene에 의해 유도되는 세포성장을 감소시켰 다(Fig. 6A). 이는, p38과 ERK MAPK가 lycopene에 의해 촉발 되는 세포성장에 관여함을 의미한다. 한편, Fig. $6 \mathrm{~B}$ 에서 보는 바와 같이 THP-1의 내피세포 부착에는 어느 억제제도 lycopene의 이종세포간 세포 부착 증진 효과를 변화시키지 않았 다. 이는 MAPK와 eNOS가 lycopene 유발 이종세포간 부착에 는 관련이 없음을 의미한다. 마지막으로 Fig. $6 \mathrm{C}$ 에서 보는 바 와 같이 lycopene에 의해 유발되는 혈관내피세포 이동은 SP-600125 (JNK 억제제) 전 처리의 경우에 세포이동이 가장 많이 억제되었다. 이는 JNK가 lycopene 유발 내피세포이동에 직접적으로 관여함을 의미한다. 내피세포이동에 JNK가 연계 되어 있음은 다른 연구에서도 확인되었다[6]. 종합해보면, lycopene에 의해 활성화되는 MAPK들은 각각 다른 내피세포활 성에 관여함을 확인하였다. 즉, ERK와 p38 MAPK는 내피세포 성장에 관여하고, $\mathrm{JNK}$ 는 내피세포이동에 각각 다르게 연계되 어 있으며, 이는 lycopene이 보다 다양한 혈관기능에 관여할
가능성이 있음을 암시한다.

\section{고 찰}

Lycopene의 함량이 많은 식물 중의 하나가 토마토이다. 토 마토(Lycopersicon esculentum)는 가지과에 속하며 원산지는 남 아메리카이다. 토마토는 전세계적으로 분포하며 국내에서도 전국 각지에서 재배되는 귀화식물 중 하나이다. 토마토의 열 매는 주로 식용으로 사용되며 식물치료(phytotherapy)에도 이 용되고 있다[12]. 토마토의 식물치료의 대상 질환은 고혈압, 당뇨병, 야맹증 등으로 알려져 있다[8]. 또한 현재 알려진 토마 토의 생리적 효능은 항암 효과 등이다[19]. 이처럼 토마토는 기능성 식품으로서 이용가치가 매우 크다.

토마토의 주요성분은 lycopene 이외에 carotene, anthocya$\operatorname{nin}$ 와 같은 항산화 물질과 비타민 C와 비타민 A 등이 있다 [11]. 토마토의 주요성분 중 하나인 lycopene은 인체에서는 생 합성 되지 않으며 식물(plant), 광합성을 하는 세균 (photosynthetic bacteria), 진균류(fungi) 그리고 조류(algae) 등에서 합성된다[23]. 식물에서 합성되는 lycopene은 빛에 의 한 식물의 손상을 막으며, 광합성과 관련한 식물의 대사에도 역할을 한다[5].

인체의 경우, 음식을 통하여 섭취된 lycopene은 소장에서 교질입자(micelles)와 결합하여 용해되어, 수동수송(passive transport) 메커니즘에 따라 장점막세포(intestinal mucosal cell)로 투과되어 혈액 내에서 지방 단백질과의 결합을 통해 수송된다. Lycopene의 체내 분포는 주로 지방이 많이 함유되 어 있는 기관인 간, 정소 그리고 부신 등에 분포된다[4].

Lycopene의 잘 알려진 기능은 항산화 기능이다. Lycopene 의 항산화 기능은 인체 내의 ROS (reactive oxygen species)를 제거하거나 산화적 손상을 감소시키며, 항암효과에도 역할을 한다[1, 25]. 기존 보고에 의하면 lycopene은 암 세포의 성장을 $\alpha$ - 또는 $\beta$-carotene 보다 효율적으로 억제하는 것으로 알려졌 다. 또한 vitamin D3와 같이 작용하여 암세포의 세포주기(cell
A

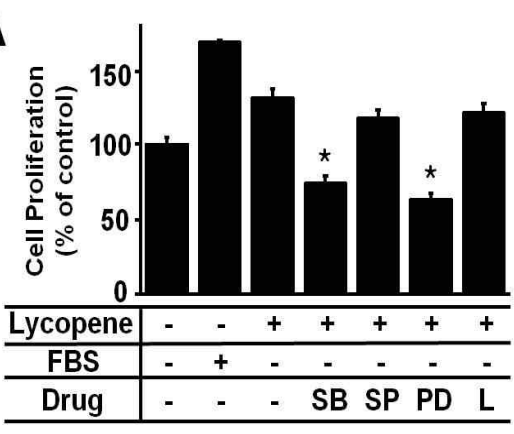

B

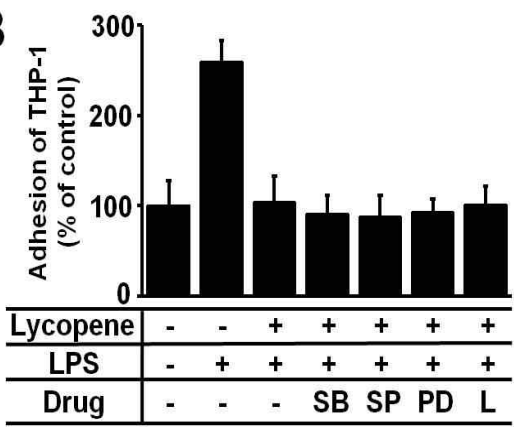

C

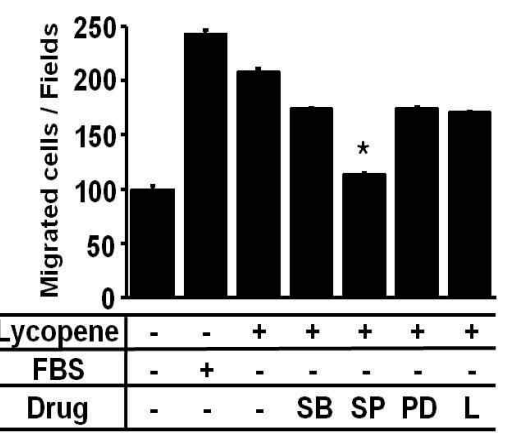

Fig. 6. ERK and p38 MAPKs induce endothelial cell proliferation, whereas JNK induces endothelial cell migration. BAECs were serum starved for $16 \mathrm{hr}$ and treated with $10 \mu \mathrm{M}$ SB-203508, $10 \mu \mathrm{M}$ SP-600125, $20 \mu \mathrm{M}$ PD-98059 or $2.5 \mu \mathrm{M}$ L-NAME for $1 \mathrm{hr}$. Then, cell proliferation (A), adhesion of THP-1 to BAECs (B), and migration (C) were analyzed as described in Methods and Materials. Bar graphs show mean \pm S.E $(n=3)$. ${ }^{*} p<0.05$ 
cycle) 진행을 억제하며 IGF-1에 의해 유도되는 세포성장을 감소시킨다[2,16]. 이와 다르게 대식세포(macrophage)에서는 HMG-CoA 환원효소(reductase) 경로를 억제하여 콜레스테롤 저하제(hypocholesterolemic agent)로서 작용된다[9]. 위에서 정리한 연구 결과들을 종합해 볼 때, lycopene은 항산화 기능 뿐 아니라, 세포 내 다양한 세포활성을 조절하는 것으로 보아, 암뿐만 아니라 혈관 기능 조절자로도 작용할 수 있을 것으로 것을 예측할 수 있다.

본 논문에서는 기존에 잘 알려지지 않은 lycopene의 혈관 내에서의 기능을 예측할 수 있는 세포실험들을 수행하여 다음 과 같은 결과들을 얻을 수 있었다. Lycopene은 혈관내피세포 의 성장 및 이동을 촉진시키며, LPS에 의해 유도되는 단핵구 의 내피세포 부착을 억제하였다. 또한 lycopene은 MAPK의 활성화를 유도하지만, $\mathrm{eNOS}$ 의 활성에는 영향이 없었다. 한편, 신호전달물질 억제제를 처리한 실험에서 lycopene에 의하여 활성화되는 ERK와 $\mathrm{p} 38 \mathrm{MAPK}$ 는 세포성장에 관여하며 JNK 는 세포이동을 조절하는 것으로 밝혀졌다. 이와 같은 결과는 lycopene이 혈관생리활성에 다양한 영향을 미치는 것을 의미 한다.

본 연구를 통해 규명된 lycopene의 혈관내피세포내의 기능 들은 lycopene이 인체의 심혈관계에서도 다양한 생리적 기능 을 보유할 개연성을 제시한다. 먼저, lycopene이 세포성장과 세포이동을 촉진하는 기능은 혈관신생과 상처 치유에 필수적 인 과정 중 하나이기 때문에 lycopene은 혈관신생 및 상처 치유 효능을 갖고 있음을 암시한다. 또한, LPS에 의해 유도되 는 THP-1의 혈관내피세포 부착의 억제는 lycopene이 혈관 내 항염증 기능을 암시하는 것으로 lycopene이 초기 동맥경화 발생을 억제시킬 것으로 예측된다. 동맥경화가 진행되는 초기 의 현상들을 단계별로 열거하면, 단핵구의 혈관내피세포 부 착, 단핵구의 내피층 내부로의 침투, 그리고 산화된 LDL의 작용으로 침투된 단핵구의 포말세포로 전환 등이다. 따라서 lycopene의 THP-1 세포의 혈관 내피세포부착 억제효과는 동 맥경화 발생을 억제하는 억제제로서 작용할 가능성이 있음을 의미한다.

본 연구의 결과를 토대로 lycopene은 혈관내피세포에 작용 하여 세포성장, 세포이동, 백혈구의 내피세포 부착과 세포 내 신호전달을 유도하는 등 내피세포의 생리활성을 조절하는 물 질임이 규명되었고, 이러한 혈관생리조절 기능을 갖는 lycopene은 심혈관계 질환의 치료제 및 혈관계의 기능 개선제로의 응용 가능성이 있는 물질이다.

\section{감사의 글}

이 연구는 2009학년도 단국대학교 대학연구비(연구년 연구 비)의 지원으로 연구되었음.

\section{References}

1. Agarwal, S. and A. Rao. 1998. Tomato lycopene and low density lipoprotein oxidation: a human dietary intervention study. Lipids 33, 981-984.

2. Amir, H., M. Karas, J. Giat, M. Danilenko, R. Levy, T. Yermiahu, J. Levy, and Y. Sharoni. 1999. Lycopene and 1,25-dihydroxyvitamin D3 cooperate in the inhibition of cell cycle progression and induction of differentiation in HL-60 leukemic cells. Nutr. Cancer 33, 105-112.

3. Christopher, K. G. and W. L. Joseph. 2001. Atherosclerosis: The Road Ahead. Cell 104, 503-516.

4. Boileau, A. C., N. R. Merchen, K. Wasson, C. A. Atkinson, and J. W. Erdman. 1999. Cis-lycopene is more bioavailable than trans-lycopene in vitro and in vivo in lymph-cannulated ferrets. J. Nutr. 129, 1176-1181.

5. Demmig-Adams, B., A. Gilmore, and W. Adams. 1996. Carotenoids 3: in vivo function of carotenoids in higher plants. FASEB J. 10, 403-412.

6. Uchida, C., E. Gee, E. Ispanovic, and T. L. Haas. 2008. JNK as a positive regulator of angiogenic potential in endothelial cells. Cell Biol. Int. 32, 769-776.

7. Cybulsky, M. I. and M. A. Gimbrone. 1991. Endothelial expression of a mononuclear leukocyte adhesion molecule during atherogenesis. Science 251, 788-791.

8. Engelhard, Y., B. Gazer, and E. Paran. 2006. Natural antioxidants from tomato extract reduce blood pressure in patients with grade- 1 hypertension: A double-blind, placebo-controlled pilot study. Am Heart J. 151, 100.e1-100.e6.

9. Fuhramn, B., A. Elis, and M. Aviram. 1997. Hypocholesterolemic effect of lycopene and b-carotene is related to suppression of cholesterol synthesis and augmentation of LDL receptor activity in macrophage. Biochem Biophys. Res. Commun. 233, 658-662.

10. Galkina, E. and K. Ley. 2009. Immune and inflammatory mechanisms of atherosclerosis. Annu. Rev. Immunol. 27, 165-197.

11. Campbell, J. K., K. Canene-Adams, B. L. Lindshield, T. W. Boileau, S. K. Clinton, and J. W. Erdman. 2004. Tomato Phytochemicals and Prostate Cancer Risk. J. Nutr. 134, 3486S-3492S.

12. Jian, Z. 2007. Nutraceuticals, Nutritional Therapy, Phytonutrients, and Phytotherapy for Improvement of Human Health: A Perspective on Plant Biotechnology Application. Recent Pat. Biotechnol. 1, 75-97.

13. Kaperonis, E. A., C. D. Liapis, J. D. Kakisis, D. Dimitroulis, and V. G. Papavassiliou. 2006. Inflammation and atherosclerosis. Eur. J. Vasc. Endovasc. Surg. 31, 386-393.

14. Karin, M. 1996. The regulation of AP-1 activity by mitogen-activated protein kinases. Philos. Trans. R. Soc. Lond B. Biol. Sci. 351, 127-134.

15. Martin, K. R., D. Wu, and M. Meydani. 2000. The effect of carotenoids on the expression of cell surface adhesion molecules and binding of monocytes to human aortic endothelial cells. Atherosclerosis 150, 265-274. 
16. Levy, J., E. Bosin, B. Feldmen, Y. Giat, A. Miinster, M. Danilenko, and Y. Sharoni. 1995. Lycopene is a more potent inhibitor of human cancer cell proliferation than either a -carotene or B-carotene. Nutr. Cancer 24, 257-266.

17. Moncada, S. and A. Higgs. 1993. The L-arginine-nitric oxide pathway. N. Engl. J. Med 329, 2002-2012.

18. Park, H., S. Park, J. Kim, Y. Ko, and S. Kim. 2002. Signaling pathways for TNF production induced by human aminoacyl-tRNA synthetase-associating factor, p43. Cytokine 20, 148-153.

19. Rao, A. and S. Agarwal. 1998. Bioavailability and in vivo antioxidant properties of lycopene from tomato products and their possible role in the prevention of cancer. Nutr. Cancer 31, 199-203.

20. Rao, A. and S. Agarwal. 1999. Role of lycopene as antioxidant carotenoid in the prevention of chronic diseases: a review. Nutr. Res. 19, 305-323.

21. Saluki-Juszczak, J. and B. Wachowicz. 2005. The proinflammatory activity of lipopolysaccharide. Postepy. Biochem 51, 280-287.

22. Schierle, J., W. Bretzel, I. Bühler, N. Faccin, D. Hess, K.
Steiner, and W. Schüep. 1997. Content and isomeric ratio of lycopene in food and human blood plasma. Food Chem $59,459-465$.

23. David, J. H. and K. J. Scott. 1995. Development and evaluation of an HPLC method for the analysis of carotenoids in foods and the measurement of carotenoid content of vegetables and fruits commonly consumed in the UK. Food Chem 54, 101-111.

24. Stahl, W. and H. Sies. 1996. Lycopene: a biologically important carotenoid for humans? Arch Biochem Biophys. 336, 1-9.

25. Wertz, K. 2009. Lycopene effects contributing to prostate health. Nutr. Cancer 61, 775-783.

26. Tang, X., X. Yang, Y. Peng, and J. Lin. 2009. Protective effects of lycopene against $\mathrm{H}_{2} \mathrm{O}_{2}$-induced oxidative injury and apoptosis in human endothelial cells. Cardiovasc. Drugs Ther. 23, 439-448.

27. Wu, W., H. Chiang, J. Fang, and C. Hung. 2007. Inhibitory effect of lycopene on PDGF-BB-induced signaling and migration in human dermal fibroblasts: a possible target for cancer: a review. Biochem Soc. Trans. 35, 1377-1378.

\section{초록 : Lycopene의 새로운 혈관내피세포 생리활성}

조진구 · 김성현 · 서정화 · 안선영 · 정은실 · 박헌용*

(단국대학교 분자생물학과, BK21 RNA 전문인력양성팀, 나노센서바이오텍연구소)

항암 효과와 항산화 기능을 가지는 것으로 알려진 lycopene은 심혈관에서의 기능이 현재까지 잘 알려져 있지 않다. 본 연구에서는 lycopene의 심혈관 기능을 알기 위해 혈관내피세포를 이용해 다양한 세포실험을 수행하였 다. 그 결과, lycopene은 내피세포의 성장 및 이동을 촉진하였으나 세포사멸에는 영향이 없었다. 또한, 백혈구의 혈관내피세포 부착을 억제하였고 내피세포 내 신호전달물질인 MAPK들의 활성을 촉발하였다. MAPK의 활성 억 제제를 이용한 신호전달기전 연구실험 결과, ERK와 p38 MAPK의 활성은 세포성장에 관여하고, JNK의 활성은 세포이동에 관여함을 확인하였다. 종합하면, lycopene은 혈관내피세포의 신호전달 물질인 MAPK들를 통해 세포 성장 및 이동을 촉진시키며, LPS에 의한 THP-1의 내피세포 부착을 억제 하는 등 혈관내피세포의 다양한 생리활 성을 조절한다. Lycopene의 이러한 혈관내피세포 기능들은 lycopene이 혈관질환 치료제로 응용될 가능성이 있음 을 의미한다. 